\title{
A workflow for bedrock thermal conductivity map to help designing geothermal heat pump systems in the St. Lawrence Lowlands, Québec, Canada
}

Jasmin Raymond Ph.D. ${ }^{1 *}$, Karine Bédard ${ }^{1}$, Félix-Antoine Comeau ${ }^{1}$, Erwan Gloaguen ${ }^{1}$, Guillaume Comeau ${ }^{2}$, Emmanuelle Millet ${ }^{2}$, Stefan Foy ${ }^{2}$

${ }^{1}$ Institut national de la recherche scientifique, Quebec, Quebec, G1K 9A9 Canada

${ }^{2}$ SNC-Lavalin Inc, Québec, Quebec, Canada

*Corresponding Author: Email: jasmin.raymond@ete.inrs.ca

\begin{abstract}
An accurate knowledge of the subsurface thermal conductivity is essential to design geothermal heating and cooling systems, more specifically ground-coupled heat pumps. The subsurface thermal conductivity has a direct impact on the length of vertical ground heat exchangers needed to fulfill building energy needs. However, mapping the distribution of the subsurface thermal conductivity is a significant challenge due to the ground heterogeneity and the limited radius of influence associated to thermal
\end{abstract}


conductivity assessment methods. Data from 79 thermal response tests, 90 thermal conductivity analyses conducted in the laboratory and geophysical well logs from 72 exploration wells were combined and analyzed all together in an attempt to map the bedrock thermal conductivity distribution of the St. Lawrence Lowlands, Québec, Canada. Results from laboratory and well log analysis were adjusted for field scale effects using thermal response tests to properly define a statistically reliable thermal conductivity for each thermostratigraphic unit of this sedimentary basin. The thermal conductivity obtained from thermal response tests and adjusted laboratory analyses was interpolated with sequential Gaussian simulations to generate a 2D bedrock thermal conductivity map, which can be used by geothermal system designers to better understand the geothermal heat pump potential of the St. Lawrence Lowlands.

Keywords: thermal response test, ground heat exchanger, ground-coupled heat pump, thermal conductivity map, sedimentary basin, sequential Gaussian simulations

\section{Introduction}

The length of ground heat exchangers (GHEs) needed for a geothermal heating and cooling system, more specifically a ground-coupled heat pump (GCHP), depends mostly on building energy needs affecting ground loads, the thermal state and properties of the subsurface and design parameters associated to the GHE field and the heat pump such as the desired operating fluid temperature, the borehole thermal resistance and the borehole spacing (Bernier 2000; Philippe et al. 2010). Designing a GCHP system to better constrain its GHE length and potential installation cost consequently requires to properly define the building energy consumption, characterize the subsurface and optimize the 
system parameters. Characterizing the subsurface to define its thermal state and properties can be challenging, especially when identifying the ground thermal conductivity.

The undisturbed subsurface temperature can be evaluated from maps with interpolation of in situ measurements (Majorowicz et al. 2009), deduced for atmospheric weather data (Signorelli and Kohl 2004; Ouzzane et al. 2015; Badache et al. 2016) or directly measured in an exploration borehole (Gehlin and Nordell 2003). The subsurface heat capacity depends on the mineral content, porosity and fluid saturation of geological materials (Waples and Waples 2004a, 2004b), but shows a small variability (Clauser 2014a) and has a low sensitivity with respect to geothermal system simulations, such that it can be reasonably defined with information about the geological record. The subsurface thermal conductivity is the remaining parameter that is more difficult to evaluate because it varies among a scale of 0.5 to $8 \mathrm{~W} \mathrm{~m}^{-1} \mathrm{~K}^{-1}$ depending on the geological materials (Clauser 2014b), according to their mineralogy, porosity and fluid saturation that are heterogeneously distributed. Moreover, the sensitivity of geothermal system simulation or design with respect to the subsurface thermal conductivity can be qualified as high. For example, a previous assessment of the subsurface thermal conductivity in the St. Lawrence Lowlands (SLL) sedimentary basin revealed that GHE length can vary by more than $50 \%$ among GCHP systems installed in the different thermostratigraphic units of this area having a low to high thermal conductivity varying below $2 \mathrm{~W} \mathrm{~m}^{-1} \mathrm{~K}^{-1}$ and above $6 \mathrm{~W} \mathrm{~m}^{-1} \mathrm{~K}^{-1}$ (Raymond, Sirois, et al. 2017). This evidences the need to assess the subsurface thermal conductivity and provide tools for geothermal system designers to better evaluate GHE length. 
The subsurface thermal conductivity can be deduced with different approaches, presented below in order of increasing reliability and representativeness: laboratory analysis on samples collected from outcrops, drilled cuttings or cores; passive in situ analysis based on the interpretation of geophysical signals; and active heat transfer experiments conduct in the field such as thermal response tests (TRTs; Raymond, 2018). The cost of each method generally increases with reliability and representativeness. TRTs remain the most reliable approach to evaluate the in situ subsurface thermal conductivity in the context of GCHP design, but cannot economically be carried out for each geothermal project. North American guidelines to design geothermal systems suggest to conduct one to three TRTs per project when the heat pump capacity varies from less than 45 to more than $100 \mathrm{~kW}$, respectively (ANSI/CSA 2016). In practice, this is difficult to apply and TRTs tend to be performed when the cost of potential borehole reduction due to uncertainty in ground thermal conductivity exceeds the cost of a TRT. Methods to evaluate the subsurface thermal conductivity are additionally spatially limited (Raymond, Malo, et al. 2017). Laboratory analysis on rock samples and geophysical well log interpretations can help define the thermal conductivity within millimeter to centimeter distances surrounding a sample or a borehole, while TRTs can have a radius of influence on the order of 1 to $2 \mathrm{~m}$ (Raymond et al. 2014). This can yield to field scale effects (Luo et al. 2016), where the apparent thermal conductivity measured at a small scale is higher than that measured at a larger scale (Jorand et al. 2013, 2015), which can be due to geological material heterogeneity inducing barriers to conductive heat transfer at larger scale. Oppositely, the bulk thermal conductivity evaluated in the field can be affected by groundwater flow increasing the apparent conductive heat transfer capacity (Bozdağ et al. 2008; Fujii et al. 
2009; Lehr and Sass 2014), and making difficult the comparison of thermal conductivity evaluated on samples and in the field (Vieira et al. 2017). Nevertheless, researchers have tried to map the thermal conductivity distribution of the subsurface based on laboratory analysis of rock samples (Di Sipio et al. 2014; Raymond, Sirois, et al. 2017), interpretation of geophysical signals (Santilano et al. 2015) or compilation of TRTs ( Raymond, Malo, et al. 2017; Malmberg et al. 2018), but the three approaches have never been combined in a comprehensive mapping exercise. How to prepare the map and adequately illustrate the results can be complex while potential use needs to be discussed. The choices are to present a map of thermal conductivity with measurements show by distinct points (Raymond, Sirois, et al. 2017), to assign a range of thermal conductivity to the different geological units (Di Sipio et al. 2014) or to interpolate thermal conductivity values based on the field observations (Teza et al. 2015; Raymond, Malo, et al. 2017; Malmberg et al. 2018) in two or three-dimensional space (Santilano et al. 2015).

The objective of the work presented in this manuscript was to develop a methodology to map the thermal conductivity distribution of the SLL, considering different sources of measurements (i.e. TRTs, laboratory analysis on rock samples and geophysical well log interpretations) based on existing algorithms. The aim was to obtain a statistically reliable map of the average thermal conductivity and its uncertainty according to the bedrock's geology. The interpretation of geophysical well logs provided 762,755 local assessments of the subsurface thermal conductivity to properly evaluate the impact of the ground heterogeneity, while results from laboratory analysis on rock samples and in situ TRTs were combined to compute sequential Gaussian simulations (SGS) of the bedrock thermal conductivity with 168 data points over an area covering 19,000 $\mathrm{km}^{2}$. The study 
area is located in the southern part of the province of Québec, where it encloses major towns such as Montreal and Québec, and is part of the strongest market for geothermal heat pump installation in Canada (Canadian GeoExchange Coalition 2012).

\section{Geological setting}

The SLL is a Cambro-Ordovician sedimentary basin bounded by the Appalachian orogenic belt to the southeast and the Precambrian basement of the Canadian Shield to the northwest (Figure 1). Sedimentary rocks of the SLL were deposited in geodynamic context evolving from a rift and a passive margin to a foreland basin (Comeau et al. 2004; Lavoie 2008). Steeply southeast dipping normal faults with a southwest-northeast direction affect the sedimentary sequences that are deepening and thickening towards the southeast (Castonguay et al. 2010). Mineralogical phases and porosity of sedimentary rock formations are expected to affect the thermal conductivity of rock units (Raymond, Sirois, et al. 2017). Cretaceous intrusions, called the Monteregians Hills (Figure 3), crosscut the sedimentary sequence of the SLL and are composed of a large variety of igneous rocks (Brisebois and Brun 1994; Feininger and Goodacre 1995). Monteregians Hill cover a limited area near the surface and have not been considered in this regional assessment of the subsurface thermal conductivity because no thermal conductivity data was available for the igneous rocks and GCHP are not commonly installed at their locations.

The SLL sedimentary bedrock is covered by unconsolidated Quaternary deposits originating from the last glaciation and following ice retreat giving birth to the Champlain Sea, which covered older Quaternary deposits of preceding glaciations 
(Globensky 1987; Légaré-Couture et al. 2018; Ross et al. 2006). The Quaternary deposits have a varying thickness; most commonly less than $10 \mathrm{~m}$, but can locally exceed $80 \mathrm{~m}$. The contribution of the Quaternary deposits to the bulk subsurface thermal conductivity has been removed from collected TRT data since this regional assessment focused on the bedrock only, where most of the information is available. The groundwater level in the SLL is relatively shallow and commonly found less than $10 \mathrm{~m}$ below the surface (Carrier et al. 2013; Laroque et al. 2015; Larocque et al. 2018), such that bedrock was assumed to be fully saturated. 




Figure 1. Location of the SLL sedimentary basin and other geological provinces of Québec (adapted from Comeau et al. 2017).

The SLL sedimentary sequence was divided in seven thermostratigraphic units following previous work to assess the deep and shallow geothermal resource potential of the sedimentary basin (Figure 2; Bédard et al. 2017; Raymond, Sirois, et al. 2017).

Thermostratigraphic units are defined in this study as consecutive geological layers of similar conductive heat transfer ability. Geological groups or formations of the SLL were 
combined or divided to define the thermostratigraphic units that are further constrained by their positions within the stratigraphic column.

The Covey Hill thermostratigraphic unit is at the base of the sequence and is composed of sandstone made of 80 to $98 \%$ quartz and 3 to $10 \%$ plagioclase. The overlying Cairnside thermostratigraphic unit is made of sandstone with more than $98 \%$ quartz, expected to affect thermal conductivity peaking in this unit because of this high content. Both units have a porosity between 4 to $6 \%$ and values can locally exceed $10 \%$ (Tran Ngoc et al. 2014). The Theresa thermostratigraphic unit is composed of quartzitic and dolomitic sandstone, with occasional dolostone increasing in proportion toward the top of the formation and where thermal conductivity is expected to decrease compared to the Cairnside unit. The Beauharnois thermostratigraphic unit, conformably overlying the Theresa unit, is dominantly made of dolomite. Matrix porosity in the Theresa and Beauharnois units is low, on the order of 1 2\% (Tran Ngoc et al. 2014), while secondary porosity can reach up to $15 \%$ in dolomitie facies due to dissolution along fractures (Bertrand et al. 2003). The Trenton-Black River-Chazy thermostratigraphic unit (Tr-BRCh) indicates a transition from passive margin to foreland basin that affected the rock type to more argillaceous material, mostly limestone with occasional dolostone and siltstone. This change in rock type is expected to affect thermal conductivity that should be decreasing upward with respect to the passive margin sequence. The limestone content decreases at the expense of clay near the top of the Tr-BR-Ch unit until the Utica unit made of calcareous mudstone and expected to have a low thermal conductivity. The overlying rocks of the Sainte-Rosalie, Loraine and Queenston groups are dominantly made of siltstone, mudstone and silty mudstone, evolving toward shale and occasionally 
containing sandstone and limestone. These three groups were classified in a single thermostratigraphic unit named Caprock for simplicity.

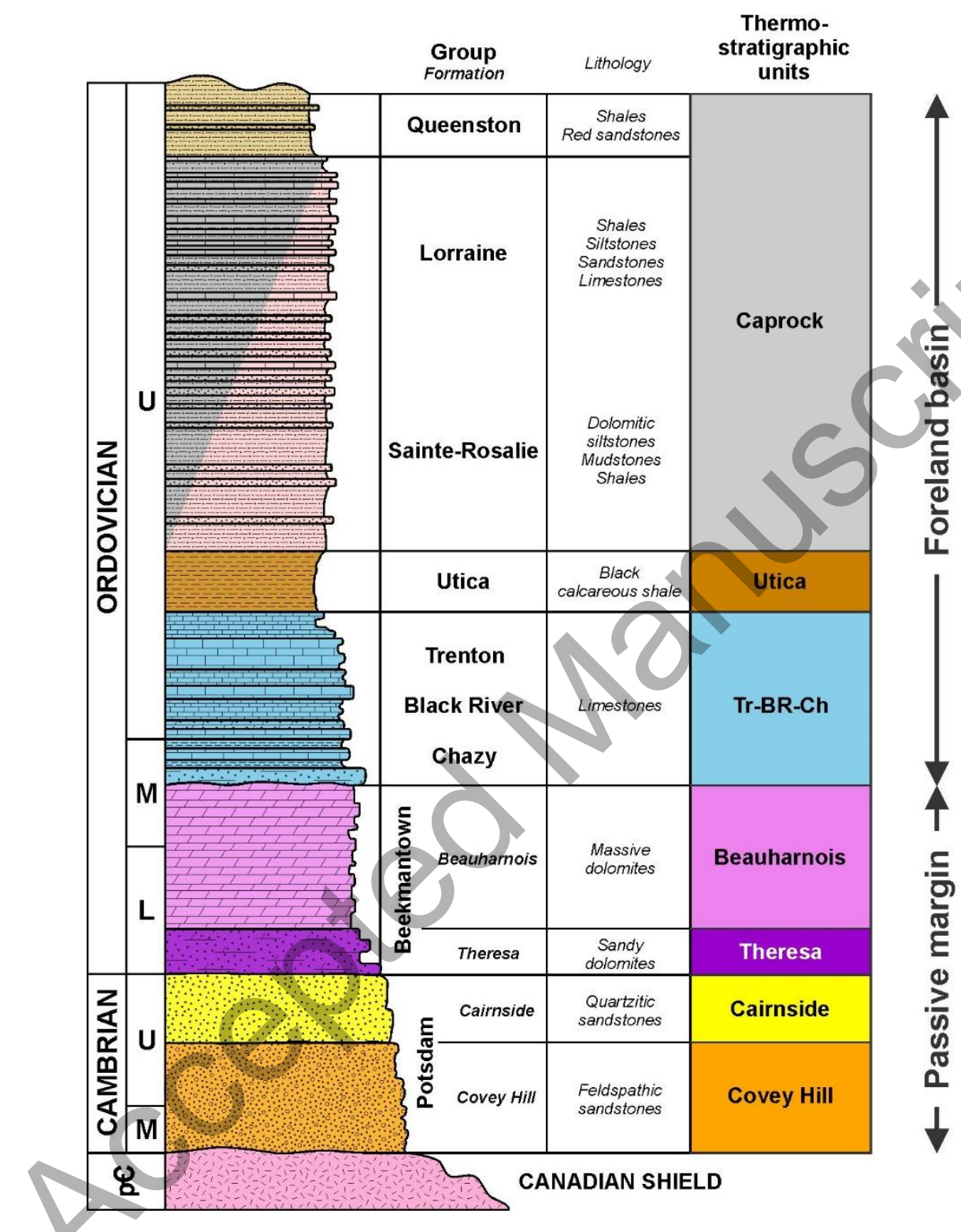

Figure 2. Stratigraphic column and thermostratigraphic units of the SLL (adapted from Comeau et al. 2004; Comeau et al. 2013; Bédard et al. 2017). 


\section{Data sources}

All sources of thermal conductivity data available for the area were compiled to evaluate the thermal conductivity of thermostratigraphic units and to map its distribution (Figure 3). A total of 79 TRTs carried by private companies and with boreholes that reached the bedrock were inventoried through reports from which the information was extracted (Table 1). The TRTs were mostly done with the conventional method, where water heated at surface is circulated in a GHE to disturb the thermal equilibrium of the ground and infer the bulk thermal conductivity (Raymond et al. 2011a). The data set involved five companies that have different TRT units, mostly having electric resistance to heat water, and that used different analysis methods, mainly based on the infinite line source equation, but for which no verification was made. The thermal conductivity values extracted from TRTs can therefore enclose experimental errors but are believed to be representative of in situ conditions. The data points are concentrated in or around the cities of Montréal and Québec, where GCHP systems are commonly installed.

Laboratory analysis of thermal conductivity realized on rock samples through various studies were also inventoried with a total of 90 data (Figure 3; Table 2). Rock samples collected from surface outcrops and analyzed with a transient needle probe (Bristow et al. 1994; Bristow and White 1994) or a modified transient plane source (MTPS; Shabbir et al. 2000; Harris et al. 2014) accounted for 61 data points (Nasr et al. 2015; Jaziri et al. 2016; Perozzi et al. 2016). Core plugs sampled from deep oil and gas exploration wells analyzed with the steady-state divided bar (Beck 1957; Beck and Beck 1958) and the MTPS methods represented an additional set of 27 data (Nasr et al. 2018). Two additionnal sites with core plugs analyzed in the laboratory, mostly with the divided bar 
method, and extracted from the Canadian heat flow database (Jessop et al. 2005) were also considered as they were located in or near the SLL study region. The laboratory data on rock thermal conductivity, considered as punctual or local assessments, relied on both transient and steady-state method. The data location covers the area between the cities of Montréal and Québec (Figure 1), where TRTs have not been performed and where outcrops or exploration boreholes were available.

Thermal conductivity inferred from geophysical well logs based on the work of Nasr et al. (2018) was inventoried for 72 oil and gas exploration wells drilled through the sedimentary sequence until a maximum depth of $4,250 \mathrm{~m}$. Signals from four reference wells crossing most of the sedimentary sequence and enclosing high quality gamma ray, density, neutron porosity, photoelectric and interval transit time logs were inverted to infer the mineralogy and porosity of rock units and to calculate their thermal conductivity with a mixing model, in the case the geometric average, similar to work achieved by Vasseur et al. (1995) or Midttømme et al. (1998). The obtained thermal conductivity profiles from the four reference wells were then used to determine empirical relationships to directly calculate the thermal conductivity, similar to work carried in other sedimentary basins (Gegenhuber and Schoen 2012; Fuchs and Förster 2013; Gasior and Przelaskowska 2014). This allowed working with limited well log signals, such as gamma ray and neutron porosity, that were widely available for a large number of wells. The empirical relationships were verified to match thermal conductivity analysis made in laboratory on core plugs from same wells (Nasr et al. 2018). The vertical resolution of geophysical well logs is on the order of centimeters while the wells covered kilometers of vertical distances, for example $4.7 \mathrm{~km}$ for three reference wells only, which allowed 
collection of 762,755 data points when considering the 72 wells. After being assigned to the thermostratigraphic unit in which they are contained, the well log data were then upscaled to decrease the vertical resolution to intervals of 75 to $150 \mathrm{~m}$, depending of thermostratigraphic thickness in wells. This step was essential to bring the data to a common scale based on TRT length. This allowed reducing the number of well log data to 498 data intervals (Table 3).

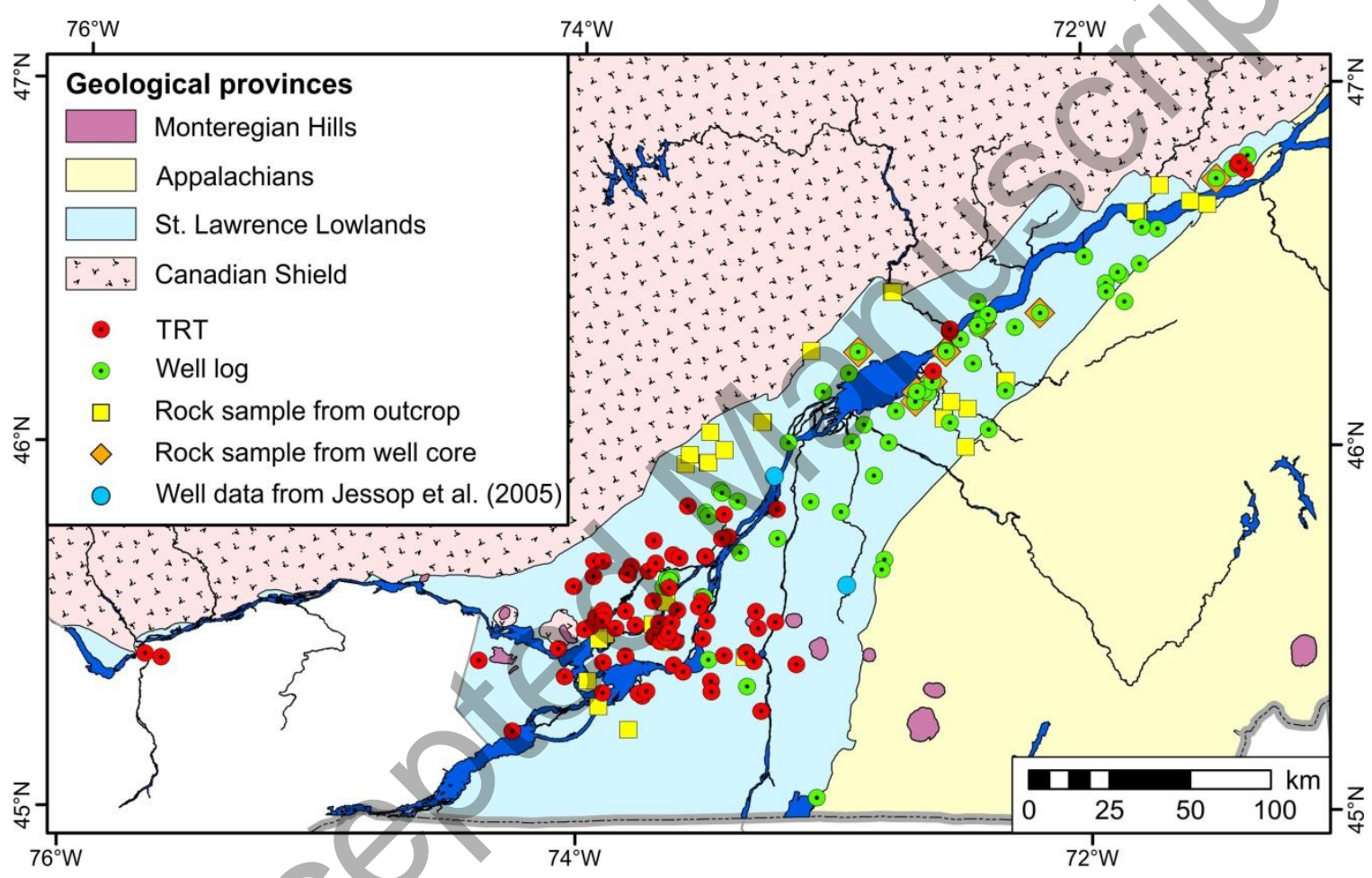

Figure 3. Data sources used for this thermal conductivity assessment of the SLL.

\section{Methodology}

The length of the boreholes $H_{\mathrm{b}}$ associated to the 79 TRTs compiled varies from 45 to $186 \mathrm{~m}$, with an average length of $141 \mathrm{~m}$. The proportion of the bedrock in each borehole was from 41 to $100 \%$ of the borehole length, with an average of almost $90 \%$. The bulk 
thermal conductivity $\lambda_{\mathrm{BULK}}$ inferred from each TRT was therefore corrected to remove the thermal conductivity attributed to the Quaternary deposits $\lambda_{\mathrm{QD}}$ on top of the bedrock and to calculate the bedrock thermal conductivity $\lambda_{\mathrm{BR}}$ with:

$\lambda_{\mathrm{BR}}=\frac{\left(\lambda_{\mathrm{BULK}} \times H_{\mathrm{b}}\right)-\left(\lambda_{\mathrm{QD}} \times H_{\mathrm{QD}}\right)}{H_{\mathrm{BR}}}$

where $\lambda\left(\mathrm{W} \mathrm{m}^{-1} \mathrm{~K}^{-1}\right)$ is the thermal conductivity and $H(\mathrm{~m})$ is the thickness over the length of the borehole $\mathrm{b}$ for the whole TRT referred as bulk value, for the bedrock BR only and for the Quaternary deposits QD. The thermal conductivity value for the Quaternary deposits was estimated from a literature review of thermal conductivity reported for unconsolidated sediments (Figure 4a). Data taken from Farouki (1981), Salomone et al. (1989), Sharma (2002), the Engineering ToolBox website (2003), the British Geological Survey (2011), Eppelbaum et al. (2014), Kavanaugh and Rafferty (2014) and GCHP design programs were considered to determine the average thermal conductivity of unconsolidated sediments $\lambda_{\mathrm{QD}}$ regardless of their type, which was $1.5 \mathrm{~W} \mathrm{~m}^{-1} \mathrm{~K}^{-1}$. Data from dried and saturated samples were indifferently mixed together because the water table is located within the Quaternary deposits, somewhere between its base and the surface on a regional scale. This value was used to determine the bedrock thermal conductivity $\lambda_{\mathrm{BR}}$ for all TRTs, which resulted in a thermal conductivity difference that was commonly less than $0.2 \mathrm{~W} \mathrm{~m}^{-1} \mathrm{~K}^{-1}$ when compared to the bulk value $\lambda_{\text {BULK }}$ since most boreholes in the inventory enclosed more than $90 \%$ bedrock (Figure 4b). A detailed stratigraphic description was available with a limited number of boreholes, such that it was sometimes possible to calculate the bedrock thermal conductivity based on the exact type of Quaternary deposits. This most commonly 
affected the bedrock thermal conductivity by $0.05 \mathrm{~W} \mathrm{~m}^{-1} \mathrm{~K}^{-1}$ or less, when compared to the value obtained using an average thermal conductivity for all Quaternary deposits regardless of their type. It was therefore decided to correct all bulk thermal conductivity values from TRTs with the same average thermal conductivity for Quaternary deposits because this simple method can easily be applied to a large set of boreholes. 


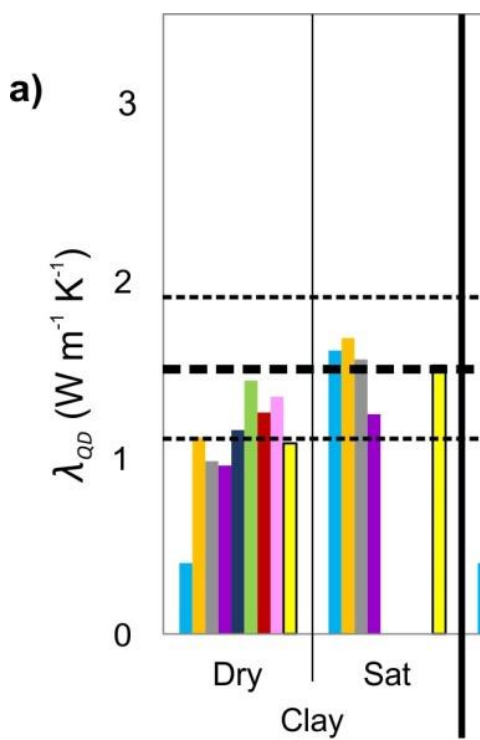

nolcon AB (2016)

- Farouki (1981)

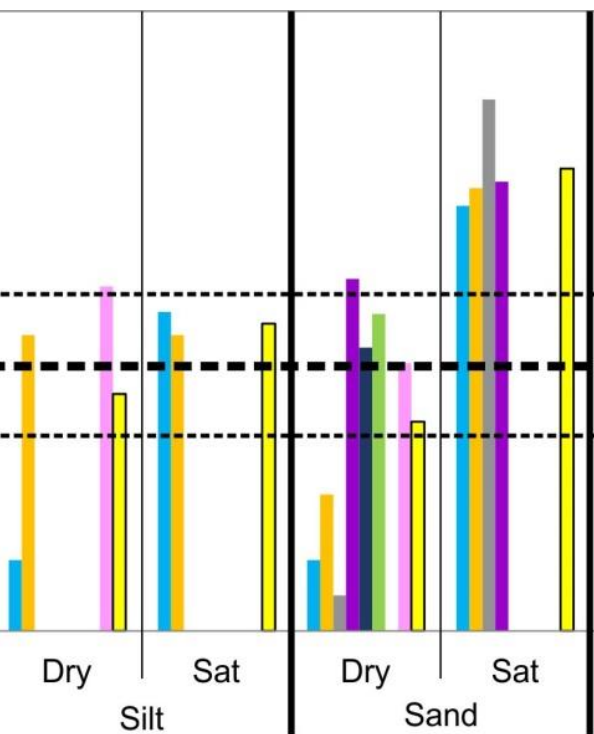

British Geological Survey (2011)

- Sharma (2002)

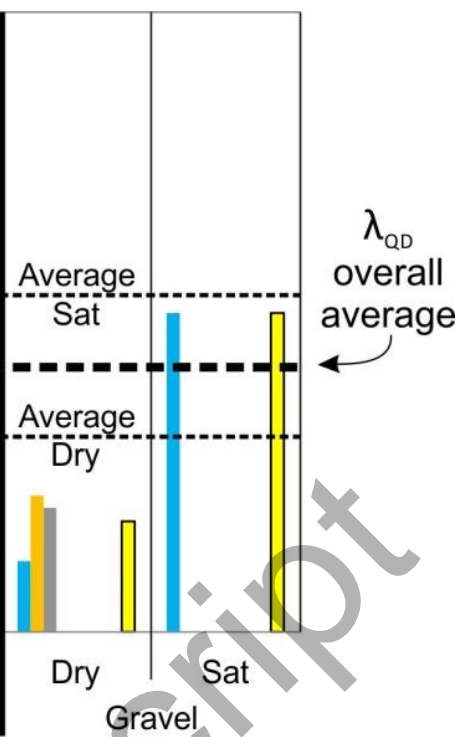

Gravel

- Kavanaugh \& Rafferty (2014) - Salomone \& Marlow (1989) $\square$ Category average

b)

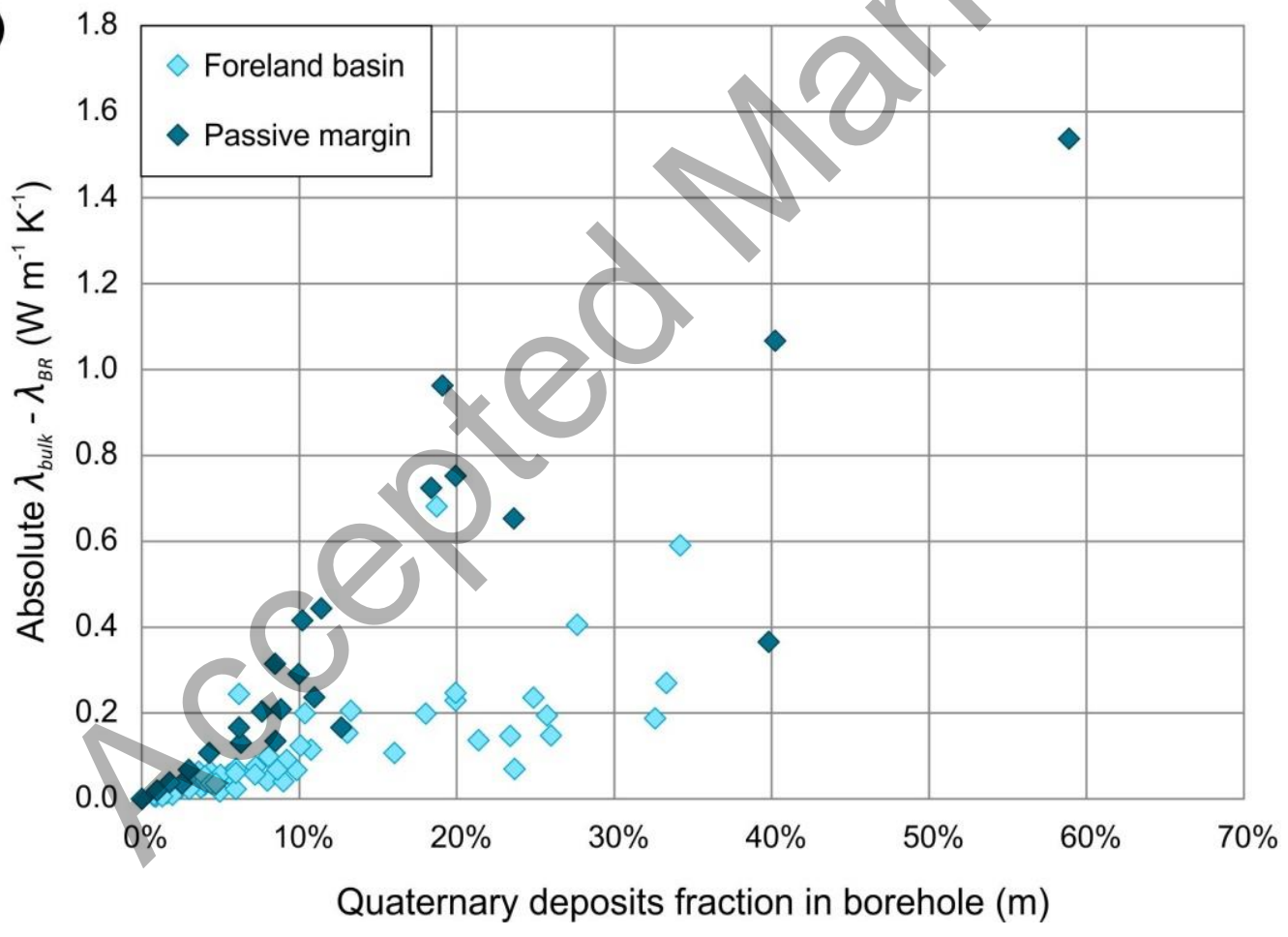

Figure 4. a) Thermal conductivity evaluated for unconsolidated sediments throughout the literature and b) absolute difference obtained when comparing bulk and bedrock thermal conductivity values associated to TRTs. Sat: saturated. 
The following statistical variables were then computed for each source of thermal conductivity data, namely corrected TRTs, laboratory analysis on rock samples and geophysical well logs interpretations, and were finally defined for each thermostratigraphic unit (Table 1; Table 2; Table 3): average, median, minimum, maximum, standard deviation, variance and interval (Max-Min). Non-negligible differences were observed between the statistical variables issued from the different data sources within single thermostratigraphic units. Indeed, the different methods have different resolution and accuracy. The corrected bedrock thermal conductivity obtained from TRTs was assumed to be representative of in situ conditions and the average found for each unit was chosen to be most representative, while their number was not sufficient to properly cover the spatial distribution. Data from geophysical well log interpretations were considered more appropriate to define the statistical distribution of thermal conductivity for the thermostratigraphic units. Consequently, the mean found from laboratory analysis on rock samples was adjusted to match the one obtained from corrected TRTs. This adjustment allowed considering field scale effects, where thermal conductivity evaluated on a centimeter scale with a sample tend to be higher than the thermal conductivity evaluated on a meter scale with a TRT (Luo et al. 2016). In the case of porous rocks with possible groundwater flow, the adjustment can have the opposite effect and increases the thermal conductivity evaluated from laboratory analysis on rock samples or geophysical well logs, which does not account for advective heat transfer when compared to the bulk thermal conductivity inferred in the field with a TRT (Vieira et al. 2017). 
Table 1 . Bedrock thermal conductivity $\lambda_{\mathrm{BR}}$ statistics obtained from an inventory of TRTs in the SLL.

\begin{tabular}{lccccccc}
\hline & \multicolumn{7}{c}{$\lambda\left(\mathbf{W ~ m}^{-\mathbf{1}} \mathbf{K}^{-\mathbf{1}}\right)$} \\
\cline { 2 - 8 } & Caprock & Utica & Tr-BR-Ch & Beauharnois & Theresa & Cairnside & Covey Hill \\
\hline Average & 2.4 & 2.4 & 2.6 & 4.2 & 3.6 & 5.0 & 3.4 \\
Minimum & 1.8 & 1.9 & 1.8 & 2.9 & 2.4 & 4.2 & 2.4 \\
Median & 2.3 & 2.3 & 2.6 & 3.9 & 3.5 & 5.4 & 3.4 \\
Maximum & 3.3 & 3.4 & 5.1 & 6.5 & 5.2 & 5.4 & 4.4 \\
Standard deviation & 0.4 & 0.5 & 0.6 & 1.0 & 1.3 & 0.7 & 1.4 \\
Variance & 0.1 & 0.2 & 0.4 & 1.0 & 1.6 & 0.5 & 2.0 \\
Interval & 1.5 & 1.5 & 3.3 & 3.6 & 2.8 & 1.3 & 2.0 \\
Number of data & 24 & 8 & 22 & 16 & 4 & 3 & 2 \\
\hline
\end{tabular}

Table 2 . Bedrock thermal conductivity $\lambda_{\mathrm{BR}}$ statistics obtained from an inventory of laboratory analysis on rock samples from the SLL.

\begin{tabular}{lccccccc}
\hline & \multicolumn{7}{c}{$\boldsymbol{\lambda}\left(\mathbf{W} \mathbf{~ m}^{-\mathbf{1}} \mathbf{K}^{-\mathbf{1}}\right)$} \\
\cline { 2 - 8 } & Caprock & Utica & Tr-BR-Ch & Beauharnois & Theresa & Cairnside & Covey Hill \\
\hline Average & 2.6 & 2.5 & 2.7 & 3.8 & 4.3 & 6.2 & 4.8 \\
Minimum & 1.4 & 1.9 & 2.1 & 2.7 & 3.1 & 5.0 & 3.1 \\
Median & 2.8 & 2.5 & 2.6 & 3.8 & 3.9 & 6.3 & 4.8 \\
Maximum & 3.6 & 2.9 & 4.2 & 4.6 & 5.9 & 6.9 & 6.6 \\
Standard deviation & 0.6 & 0.3 & 0.5 & 0.6 & 1.4 & 0.6 & 1.2 \\
Variance & 0.4 & 0.1 & 0.2 & 0.4 & 2.1 & 0.4 & 1.5 \\
Interval & 2.2 & 1.0 & 2.1 & 1.9 & 2.8 & 1.9 & 3.5 \\
Number of data & 22 & 9 & 25 & 10 & 3 & 8 & 13 \\
\hline
\end{tabular}


Table 3. Bedrock thermal conductivity $\lambda_{\mathrm{BR}}$ statistics obtained from an inventory of geophysical well log interpretations from oil and gas exploration wells in the SLL.

\begin{tabular}{lccccccc}
\hline & \multicolumn{7}{c}{$\boldsymbol{\lambda}\left(\mathbf{W} \mathbf{~ m}^{-\mathbf{1}} \mathbf{K}^{-\mathbf{1}}\right)$} \\
\cline { 2 - 8 } & Caprock & Utica & Tr-BR-Ch & Beauharnois & Theresa & Cairnside & Covey Hill \\
\hline Average & 2.6 & 3.0 & 3.4 & 3.6 & 4.5 & 6.3 & 4.6 \\
Minimum & 1.6 & 1.9 & 2.0 & 2.7 & 2.9 & 4.3 & 3.1 \\
Median & 2.4 & 3.1 & 3.6 & 3.7 & 4.5 & 6.3 & 4.8 \\
Maximum & 4.4 & 4.3 & 4.7 & 4.9 & 5.8 & 7.0 & 5.8 \\
Standard deviation & 0.5 & 0.4 & 0.5 & 0.5 & 0.6 & 0.6 & 0.7 \\
Variance & 0.3 & 0.2 & 0.3 & 0.2 & 0.4 & 0.4 & 0.5 \\
Interval & 2.8 & 2.3 & 2.6 & 2.2 & 2.8 & 2.6 & 2.7 \\
Number of data & 250 & 77 & 81 & 24 & 16 & 23 & 27 \\
\hline
\end{tabular}

SGS algorithm was used to interpolate 2D maps of the thermal conductivity and to assess its uncertainty (Goovaerts 1997). The algorithm relies on a random path to simulate thermal conductivity at unknown cells considering fixed values at cells with existing data. Once thermal conductivity is interpolated at an unknown cell, the value is incorporated to the data set to determine the value of the next cell along the random path. This method is appropriate to simulate continuous properties, such as thermal conductivity, and allows to obtain as many realizations as there are random paths that each respect the statistical distribution (Srivastava 1994). In order to comply with the simulation theory, the spatial correlation was computed with the corrected TRTs and the adjusted laboratory analysis of rock samples from surface outcrops. The variance of the thermal conductivity was taken from the 75 to $150 \mathrm{~m}$ intervals of the well log data for each thermostratigraphic unit. The thermal conductivity data were normal transformed and the experimental variogram was calculated in the normal (Gaussian) space, according to the geostatistical theory. The experimental variogram was modeled with a spherical 
function and allowed, together with bedrock thermal conductivity data, to compute multiple realization of the thermal conductivity and its statistics using the average and the variance for each $1 \mathrm{~km}^{2}$ cell of the mesh covering the simulated domain according to the workflow given in Figure 5.

The simulations were calculated independently for each thermostratigraphic unit as they do not show the same mean and variance for the thermal conductivity. For example, only data from the Covey Hill thermostratigraphic unit were used to define the spherical variogram prior to simulations. However, the number of bedrock thermal conductivity data from corrected TRTs and adjusted laboratory analysis on rock samples was too limited, which means that the parameters of the associated variogram (i.e., range, azimuth and nugget effect) could not be calculated. To overcome this problem, ranges and azimuths were actually determined according to the geometry of the SLL basin, where the sedimentary sequence is preferably oriented northwestward-southeastward. Thereby, the resulting variogram for each of the nine thermostratigraphic units are all anisotropic with the same range and azimuth to form a major and minor axes of $80 \mathrm{~km} / \mathrm{N} 045^{\circ}$ and 40 $\mathrm{km} / \mathrm{N} 315^{\circ}$, with a nugget effect that was established at $10 \%$ of the variance, which was computed from geophysical well log interpretations. The simulation results were converted back in the original non-Gaussian space through inverse Gaussian anamorphosis. The simulation average was computed in order to get the e-type (Journel and Huijbregts 1968), allowing proper representation of extreme values and considering a certain degree of smoothing for realistic simulations of each thermostratigraphic unit. 


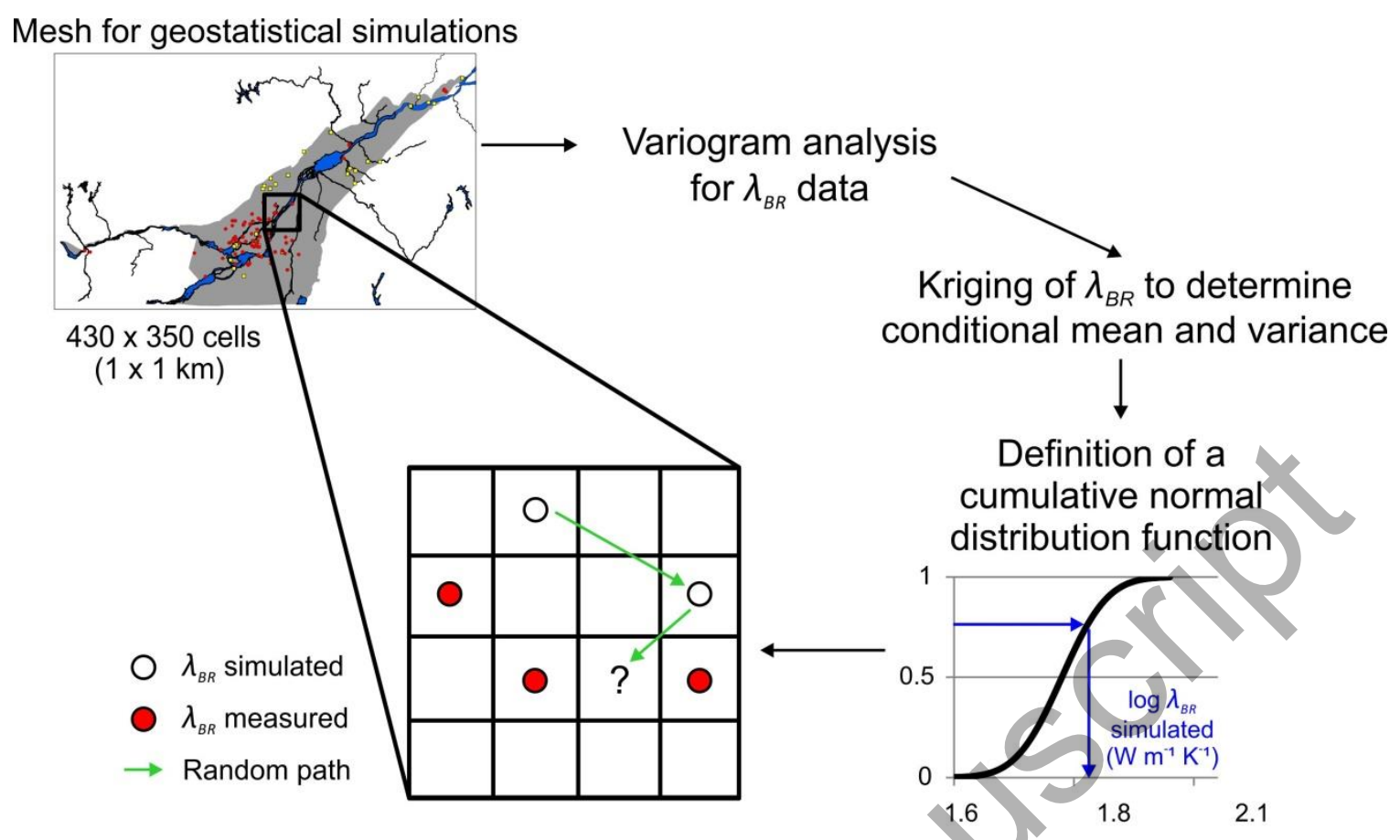

Figure 5. Steps followed for SGS of bedrock thermal conductivity in the SLL (adapted from Bédard et al. 2016).

One year after the map was defined, a set of twelve new TRTs became available. The thermal conductivity values obtained from the TRTs were compared to those anticipated from the map. Sizing calculations were then performed with the bulk thermal conductivity obtained from the TRTs and that found with the map, taking into account the Quaternary deposits thickness to calculate the bulk thermal conductivity. The sizing approach proposed by Bernier (2000) was used to schematize the building heating loads with three heat pulses for a medium size apartment building taken from an open database (Office of Energy Efficiency \& Renewable Energy, 2013) and having annual average, monthly average and a $50 \%$ peak loads of $19.8,58.1$ and $82.9 \mathrm{~kW}$, respectively, with a peak load duration of $2 \mathrm{hrs.} \mathrm{A} \mathrm{Climate} \mathrm{Master} \mathrm{TMW600} \mathrm{heat} \mathrm{pump} \mathrm{was} \mathrm{selected} \mathrm{to} \mathrm{fulfill}$ the energy needs and the system was designed for a 10 year period. The finite line source 
equation (Lamarche and Beauchamp 2007) was used to calculate the borehole temperature that was linked to the GHE fluid temperature with the multipole method to calculate the borehole thermal resistance with 10 multipoles (Claesson and Hellström 2011). The computations were done with PyGLD, a Python library for ground loop design calculations, made by Gosselin (2018). The system required 30 boreholes that were equally spaced by $6 \mathrm{~m}$ and distributed in a rectangular shape. Other design parameters that were assumed constant are given in Table 4. In this way, the subsurface thermal conductivity remains the only variable to better evaluate its impact and the accuracy of the map distribution.

Table 4. Constant GHE parameters considered for sizing calculations

\begin{tabular}{ccc}
\hline Parameter & Value & Unit \\
\hline Grout thermal conductivity & 1.70 & $\mathrm{~W} \mathrm{~m}^{-1} \mathrm{~K}^{-1}$ \\
Pipe thermal conductivity & 0.40 & $\mathrm{~W} \mathrm{~m} \mathrm{~K}^{-1}$ \\
Grout heat capacity & 3.40 & $\mathrm{MJ} \mathrm{m}^{3} \mathrm{~K}^{-1}$ \\
Subsurface heat capacity & 2.30 & $\mathrm{MJ} \mathrm{m}^{3} \mathrm{~K}^{-1}$ \\
\hline Subsurface temperature & 8 & ${ }^{\circ} \mathrm{C}$ \\
Borehole diameter & 152.40 & $\mathrm{~mm}$ \\
\hline Pipe outside diameter & 42.16 & $\mathrm{~mm}$ \\
\hline Pipe inside diameter & 33.99 & $\mathrm{~mm}$ \\
\hline Pipe spacing & 93.83 & $\mathrm{~mm}$ \\
Pipe shape & 1 & $\mathrm{U}$ \\
Total fluid flow rate & 6.65 & $\mathrm{~L} \mathrm{~s}{ }^{-1}$ \\
\hline Mropylene glycol concentration in water & 15 & $\%$ vol. \\
\hline Minimum entering water temperature & 0 & ${ }^{\circ} \mathrm{C}$ \\
\hline
\end{tabular}

\section{Results}

The results enclose a set of statistics to evaluate the bedrock thermal conductivity from TRTs, laboratory analysis on rock samples and geophysical well log interpretations. They 
can be used by a geothermal system designer to anticipate the range of thermal conductivity expected for thermostratigraphic units of the SLL. The 2D geostatistical simulations of the bedrock thermal conductivity are representative of the near-surface spatial distribution, since data were from boreholes with a maximum depth of $186 \mathrm{~m}$. The bedrock is thus considered as a single uniform layer without thermostratigraphic stacking over the length of the borehole. This assumption is based on the fact that the thermostratigraphic units have an average thickness greater than 200 meters (Globensky 1993), thus limiting the possibility of a TRT borehole to cross more than one unit in depth.

\subsection{Bedrock thermal conductivity statistics}

A change in the sediment origin can affected the mineralogy and consequently the thermal conductivity of the bedrock. The inventory of bedrock thermal conductivity obtained from TRTs shows that the thermostratigraphic units of the SLL can be divided into two distinct groups (Figure 2; Figure 4: 1) the passive margin, outcropping in the southwest of the basin and having values commonly above $3 \mathrm{~W} \mathrm{~m}^{-1} \mathrm{~K}^{-1}$ (Figure 6; 2), and the foreland basin, outcropping in the northeast part of the basin and showing thermal conductivity values commonly below $3 \mathrm{~W} \mathrm{~m}^{-1} \mathrm{~K}^{-1}$ (Figure 3; Figure 6; Figure 7a). The switch from the passive margin to the foreland basin indicates a change in depositional environment in which the rocks were formed, mainly shallow marine at the base of the sequence, mostly clean sandstones and carbonates, versus deep marine environments that provide higher clay material above the unconformity. The average thermal conductivity for the foreland basin units is between 2 and $3 \mathrm{~W} \mathrm{~m}^{-1} \mathrm{~K}^{-1}$, according to TRTs (Figure 7a; Figure 7d; Table 1). 




Figure 6. Bedrock thermal conductivity obtained from the inventory of TRTs in the SLL.

The trend in average thermal conductivity obtained from laboratory analysis conducted on rock samples is similar to that obtained from TRTs (Figure 7b; Table 2), with a few noticeable discrepancies. The peak in average thermal conductivity associated to the Cairnside unit is $6.2 \mathrm{~W} \mathrm{~m}^{-1} \mathrm{~K}^{-1}$ and all thermostratigraphic units have a higher thermal conductivity except for the Beauharnois unit, which is lower. The amount of data per unit is more evenly distributed when comparing laboratory analysis on rock samples to TRTs. The same observation can be noticed for the thermal conductivity distribution inferred from the interpretations of geophysical well logs (Figure 7c; Table 3), which is not surprising since the empirical relationships to convert geophysical well logs signals in thermal conductivity values was adjusted according to laboratory measurements of thermal conductivity made on core plugs (Nasr et al. 2018). 




Figure 7. Bedrock thermal conductivity of the SLL units determined from a) TRTs, b) laboratory analysis on rock samples, c) geophysical well log interpretations over 75 to $150 \mathrm{~m}$ intervals. The result of the adjusted outcrop rock samples on the average of the TRTs is combined with all TRT values d) in order to generate the input $\lambda_{B R}$ measured data for the SGS algorithm used for the 2D map interpolation. n: number of values.

The average thermal conductivity of the thermostratigraphic units associated to the foreland basin obtained from laboratory analysis on rock samples had to be decreased by at most $0.1 \mathrm{~W} \mathrm{~m}^{-1} \mathrm{~K}^{-1}$ to match the average obtained from the TRTs (Figure 7d; Table 5). A subtraction of at most $1.4 \mathrm{~W} \mathrm{~m}^{-1} \mathrm{~K}^{-1}$ had to be realized for the units below the 
Beauharnois thermostratigraphic unit to match the average thermal conductivity of the TRTs. Interestingly, the Beauharnois thermostratigraphic unit behaved differently. Its average thermal conductivity had to be increased by $0.4 \mathrm{~W} \mathrm{~m}^{-1} \mathrm{~K}^{-1}$ for the laboratory analysis on rock samples values to match those of the TRTs (Figure 7d; Table 5). The thermal conductivity distribution obtained from geophysical well log intervals of 75 to $150 \mathrm{~m}$ is believed to be most representative and a fair compromise considering in situ conditions and host rock heterogeneity (Figure 7c).

Table 5. Differences in average thermal conductivity of the bedrock $\lambda_{\mathrm{BR}}$ obtained from TRTs compared to laboratory analysis on rock samples.

\begin{tabular}{lc}
\hline $\begin{array}{l}\text { Thermostratigraphic } \\
\text { units }\end{array}$ & $\begin{array}{c}\lambda \text { difference between } \\
\text { TRTs and rock samples } \\
\left(\mathbf{W} \mathbf{~ m}^{-1} \mathbf{K}^{-1}\right)\end{array}$ \\
\hline Caprock & -0.2 \\
Utica & -0.1 \\
Tr-BR-Ch & -0.1 \\
Beauharnois & 0.4 \\
Theresa & -0.7 \\
Cairnside & -1.2 \\
Covey Hill & -1.4 \\
\hline
\end{tabular}

\subsection{Bedrock thermal conductivity simulations}

The map showing the distribution of the bedrock thermal conductivity is a combination of the geostatistical simulations realized for each thermostratigraphic unit (Figure 8). The average of the 100 realizations made for each of the seven units was used in the final map preparation. The average simulation results of each thermostratigraphic unit were cropped at the unit boundaries (Figure 8a) and then combined to have the average 
bedrock thermal conductivity distribution (Figure $8 b$ ) and its standard deviation over the entire simulation domain (Figure 8c).

A sharp contrast in thermal conductivity can be observed between the passive margin and the foreland basin units (Figure 2; Figure 7), leading to higher values to the southwest and lower values to the northeast (Figure 8b). The standard deviation, which gives an idea of the uncertainty associated to the bedrock thermal conductivity simulation, is below $0.5 \mathrm{~W} \mathrm{~m}^{-1} \mathrm{~K}^{-1}$ for the thermostratigraphic units of the foreland basin (Figure 8c). These units tend to be more homogenous and show a compact thermal conductivity statistical distribution, when compared to the other units having a standard deviation of more than $0.5 \mathrm{~W} \mathrm{~m}^{-1} \mathrm{~K}^{-1}$ and a wider statistical distribution indicating heterogeneity.

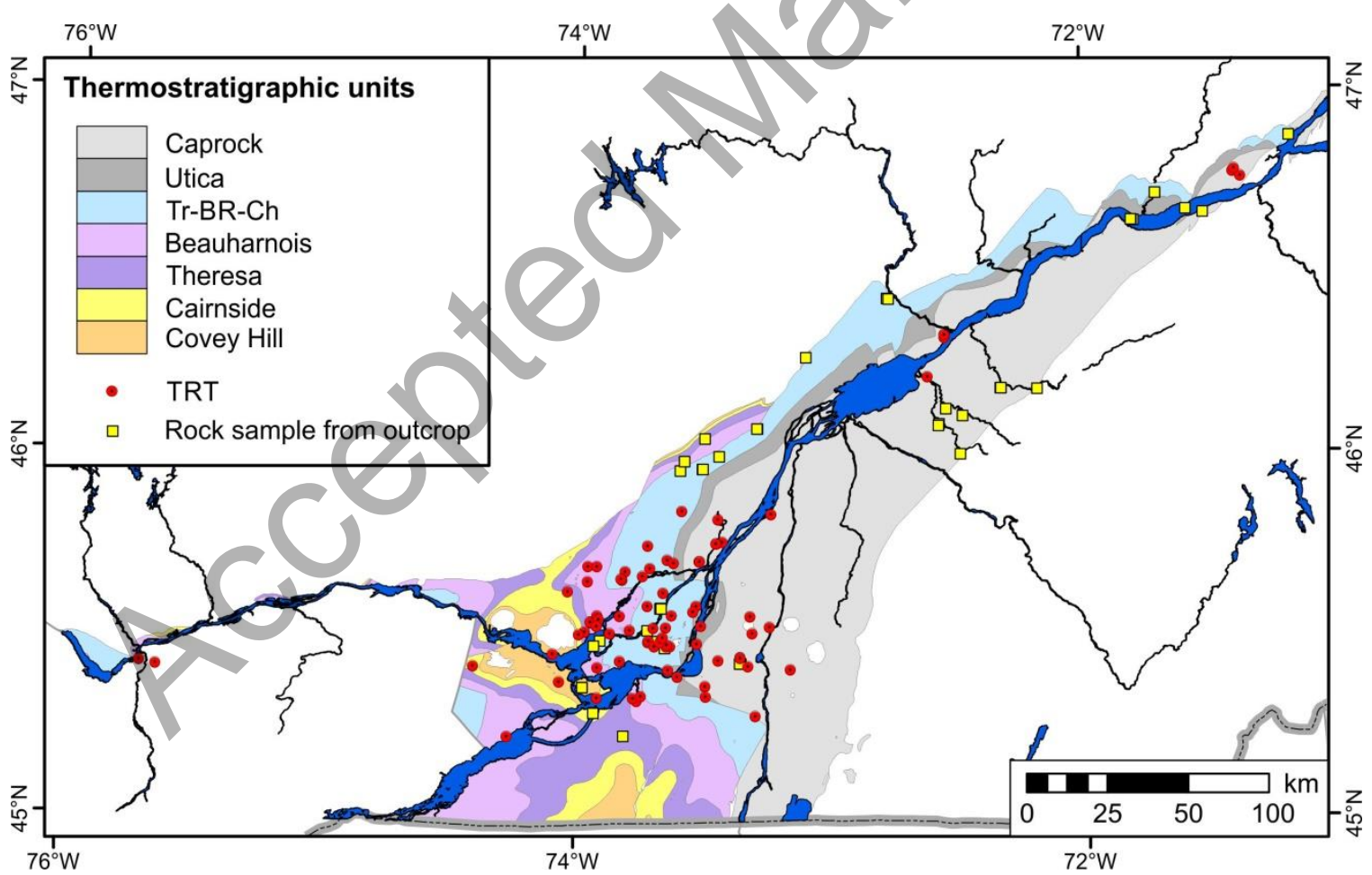



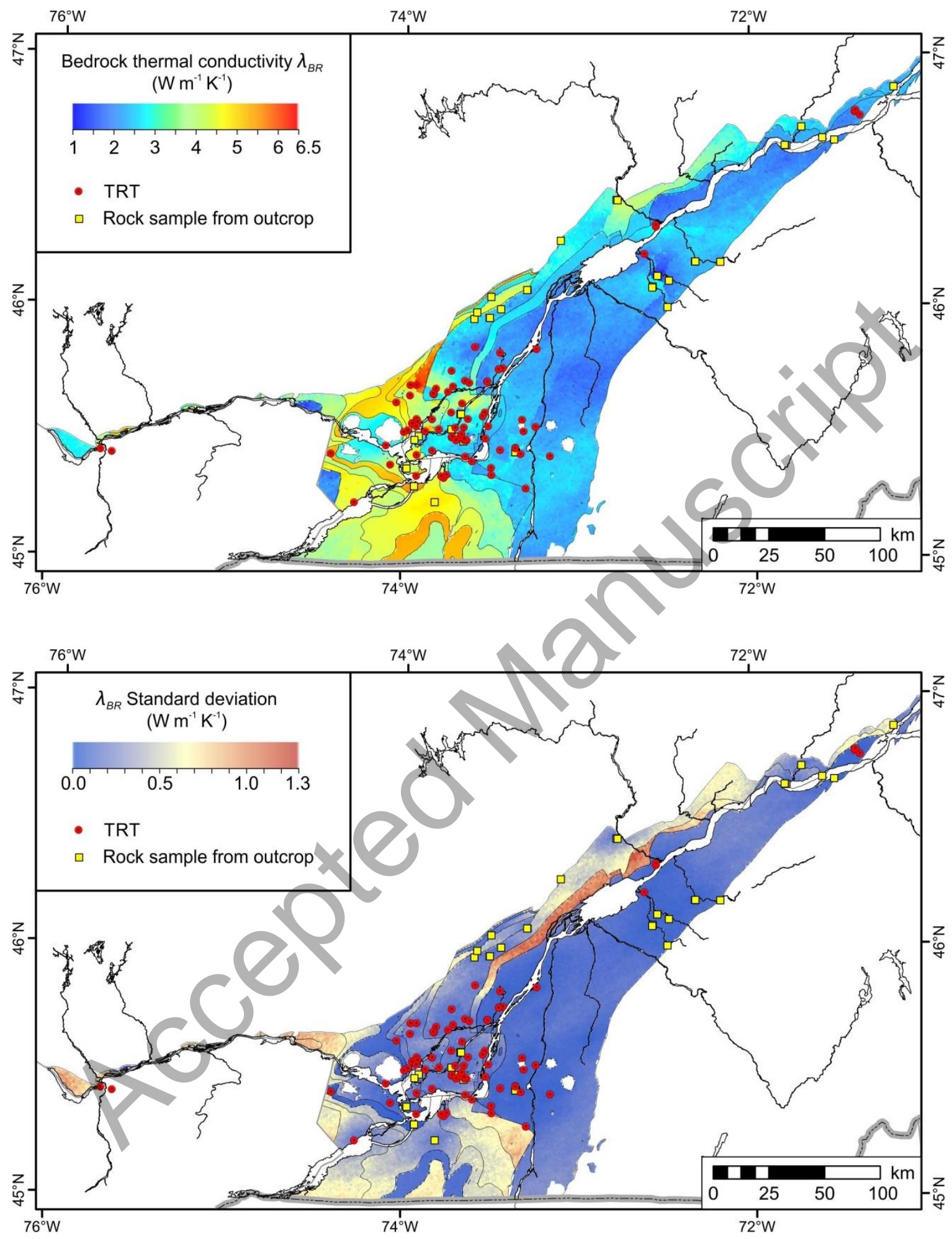
Figure 8. a) Domain considered for geostatistical simulations to determine the b) average bedrock thermal conductivity distribution and c) its standard deviation in the SLL and around.

The maps shown in Figure 8 can help estimate the range of bedrock thermal conductivity over a given area. A geothermal system designer wishing to use the maps to find the bulk thermal conductivity $\left(\lambda_{\mathrm{BULK}}\right)$ at a given location has to consider the thickness of Quaternary deposits associated to the location (Figure 9). In fact, the probable range of bulk thermal conductivity can be calculated with eq.1 over the length of a borehole $H_{\mathrm{b}}$ knowing the thickness of Quaternary deposits $H_{Q D}$ from a priori knowledge or from data such as Figure 9, the average thermal conductivity of unconsolidated Quaternary deposits from Figure $4 \mathrm{a}\left(\lambda_{Q D}=1.5 \mathrm{~W} \mathrm{~m}^{-1} \mathrm{~K}^{-1}\right)$ and the average thermal conductivity of the bedrock $\lambda_{B R}$ from Figure $8 \mathrm{~b}$ and $\mathrm{c}$.

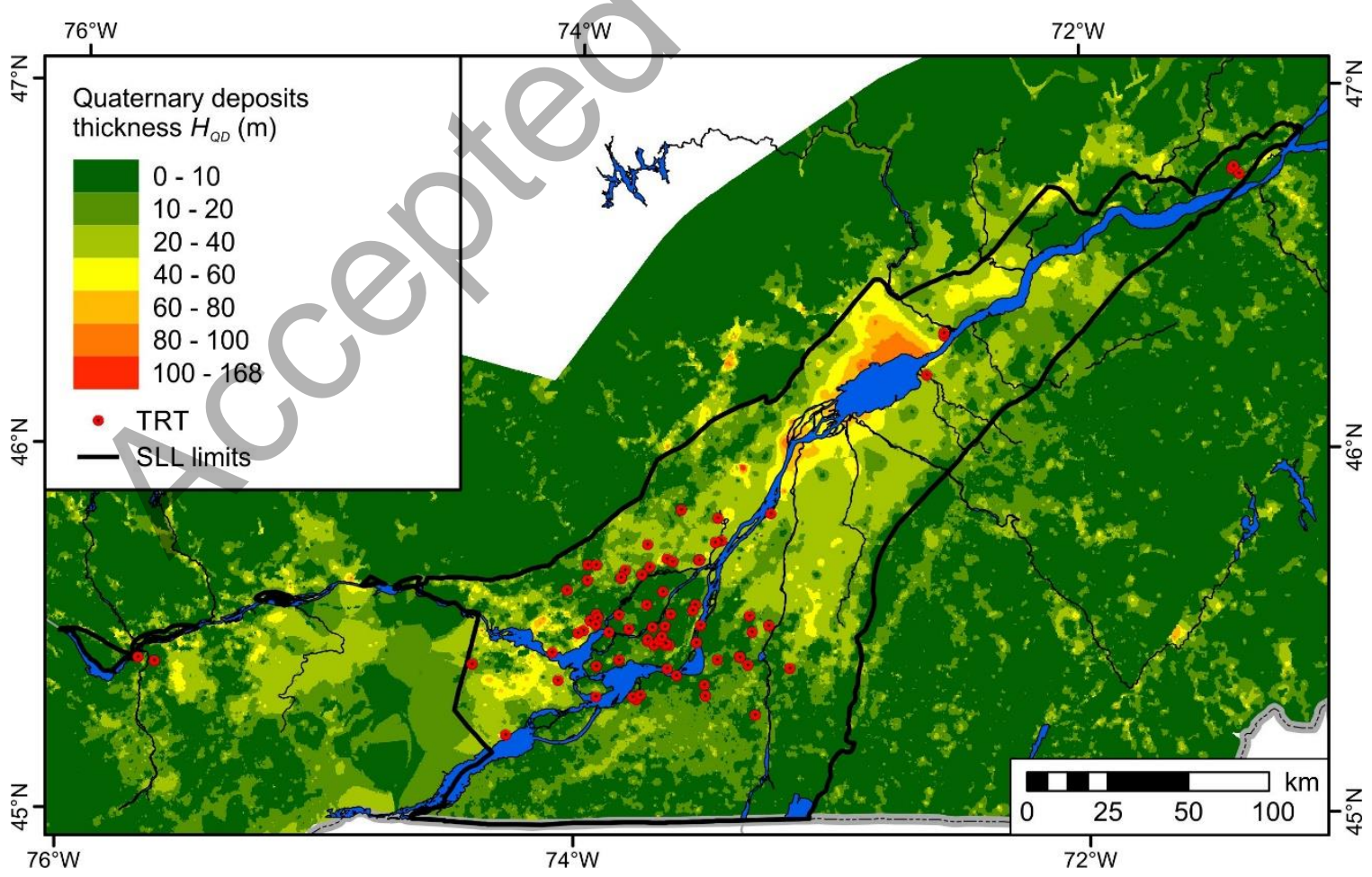


Figure 9. Thickness of the unconsolidated sediments (Quaternary deposits) in the SLL. Modified from Natural Resources Canada (2012).

The evaluation of the maps representativeness made by comparing the bulk thermal conductivity from new TRT data collected after the maps have been done to the bulk thermal conductivity evaluated from the maps assumes that the most representative value is that of TRTs, which sits at the denominator when calculating differences in percentages. This comparative analysis, giving hints on the map accuracy, shows differences ranging from -15 to $+36 \%$ for the bulk thermal conductivity (Table 6 ). The map thermal conductivity predictions are within less than $20 \%$ of TRT results for more than $75 \%$ of the twelve cases analyzed. Comparison of bedrock thermal conductivity extracted from TRTs with that evaluated from the maps revealed a similar trend as that observed for the bulk thermal conductivity. This is because the thickness of Quaternary deposits determined from drill log obtained with the TRTs is, most of the time, within a reasonable value to that evaluated with the Quaternary deposits thickness map (Figure 9). Factors that can explain the discrepancies in thermal conductivity between the map and the new TRT data are of different origins. First, TRTs can enclose experimental error or even bias since no verification was made for the work conducted by the private company that supplied the data. In situ conditions, like local groundwater flow, can further affect a restricted number of tests that can reveal a thermal conductivity at the edge of the statistical distribution expected for its thermostratigraphic unit. The amount of data point in a given unit can be small, resulting in map uncertainty. This is especially true where the standard deviation of simulated thermal conductivity is high (Figure 8). Further errors can be due to the correction made to account for the thickness of Quaternary deposits and 
its impact on thermal conductivity. Nevertheless, the sizing calculations made to evaluate the map usefulness and performed for the mid-size apartment building with the bulk thermal conductivity from TRTs compared to bulk the thermal conductivity from the maps indicate potential discrepancy in total borehole length $\left(L_{b}\right)$ of less than $17 \%$ (Table 6). This is significantly low, considering that the total range of bulk thermal conductivity difference between the map and the TRT is up to $36 \%$. The maps appears to reveal a thermal conductivity distribution that is representative and can potentially undersize GHE length $67 \%$ of the time and oversize GHE length for the remaining $33 \%$, which is well distributed considering that only twelve new TRTs were available for this verification and evaluation of the map usefulness. 
Table 6. Verification of thermal conductivity values obtained from the map with comparison of new TRT data.

\begin{tabular}{|c|c|c|c|c|c|c|c|c|c|c|c|c|c|c|}
\hline \multirow[b]{2}{*}{ Latitude } & \multirow[b]{2}{*}{ Longitude } & \multirow{2}{*}{$\begin{array}{l}\text { Thermostrati- } \\
\text { graphic unit }\end{array}$} & \multirow{2}{*}{$\begin{array}{l}H_{\mathrm{b}} \\
(\mathbf{m})\end{array}$} & \multicolumn{3}{|c|}{ TRT } & \multicolumn{3}{|c|}{ Map } & \multicolumn{2}{|c|}{ Map - TRT (\%) } & \multicolumn{2}{|c|}{$L_{\mathrm{b}}(m)$} & \multirow{2}{*}{$\begin{array}{c}\text { Diff } \\
\boldsymbol{L}_{\mathrm{b}} \\
(\%)\end{array}$} \\
\hline & & & & $\begin{array}{c}\lambda_{\text {BULK }} \\
\left(W^{-1} \mathbf{m}^{-1}\right)\end{array}$ & $\begin{array}{c}\boldsymbol{H}_{\mathrm{QD}} \\
(\mathbf{m})\end{array}$ & $\left(\begin{array}{c}\lambda_{\mathrm{BR}} \\
\left(\mathbf{W}^{-1} K^{-1}\right)\end{array}\right.$ & $\begin{array}{c}\lambda_{\mathrm{BR}} \\
\left.\mathbf{W} \mathbf{m}^{-1} \mathbf{K}^{-1}\right)\end{array}$ & $\begin{array}{c}\boldsymbol{H}_{\mathrm{QD}} \\
(\mathbf{m})\end{array}$ & $\begin{array}{c}\lambda_{\text {BULK }} \\
\left(W^{-1} \mathbf{m}^{-1}\right)\end{array}$ & $\lambda_{\mathrm{BULK}}$ & $\lambda_{\mathrm{BR}}$ & TRT & Map & \\
\hline 46.7957 & 71.3028 & Caprock & 154 & 1.75 & 10 & 1.77 & 2.22 & 14 & 2.15 & 23 & 25 & 3,745 & 3,317 & -11 \\
\hline 45.7916 & -73.4129 & Caprock & 155 & 1.63 & 44 & 1.68 & 2.08 & 31 & 1.96 & 20 & 24 & 3,904 & 3,504 & -10 \\
\hline 45.5848 & -73.1868 & Caprock & 155 & 2.32 & 24 & 2.47 & 2.09 & 28 & 1.98 & -15 & -15 & 3,171 & 3,483 & 10 \\
\hline 45.7726 & -73.3574 & Caprock & 162 & 2.26 & 32 & 2.45 & 2.35 & 33 & 2.18 & -4 & -4 & 3,220 & 3,290 & 2 \\
\hline 45.4877 & -73.452 & Caprock & 162 & 2.40 & 7 & 2.44 & 2.18 & 6 & 2.15 & -10 & -11 & 3,107 & 3,317 & 7 \\
\hline 46.7957 & -71.3028 & Caprock & 165 & 1.72 & 10 & 1.73 & 2.22 & 14 & 2.16 & 26 & 28 & 3,783 & 3,308 & -13 \\
\hline 45.7143 & -73.6709 & Tr-BR-Ch & 155 & 1.97 & 52 & 2.21 & 2.62 & 58 & 2.20 & 12 & 19 & 3,493 & 3,272 & -6 \\
\hline 45.5596 & -73.702 & Tr-BR-Ch & 156 & 2.34 & 8 & 2.38 & 2.89 & 6 & 2.84 & 21 & 21 & 3,154 & 2,808 & -11 \\
\hline 45.5612 & -73.6107 & Tr-BR-Ch & 156 & 2.48 & 3 & 2.50 & 2.67 & 2 & 2.66 & 7 & 7 & 3,047 & 2,921 & -4 \\
\hline 45.574 & -73.5787 & Tr-BR-Ch & 162 & 2.43 & 6 & 2.47 & 2.84 & 1 & 2.83 & 17 & 15 & 3,084 & 2,814 & -9 \\
\hline 45.4749 & -73.862 & Tr-BR-Ch & 162 & 2.63 & 4 & 2.66 & 2.61 & 4 & 2.58 & -2 & -2 & 2,941 & 2,975 & 1 \\
\hline 45.6676 & -73.7636 & Tr-BR-Ch & 186 & 2.31 & 11 & 2.36 & 3.26 & 12 & 3.15 & 36 & 38 & 3,179 & 2,636 & -17 \\
\hline
\end{tabular}




\section{Discussion and conclusions}

The statistics presented in this manuscript offers a comprehensive inventory of bedrock thermal conductivity for the SLL sedimentary basin. The concept of thermostratigraphy developed for the study of deep geothermal resources (Gosnold et al. 2012; Sass and Götz 2012) was adapted to study shallow geothermal resources of GCHP systems (Raymond, Sirois, et al. 2017) and used in this work to evaluate the conductive heat transfer potential of rock sequences. Not only were laboratory analysis on rock samples used, but TRTs and geophysical well log interpretations were also considered to build on previous assessments of the subsurface thermal conductivity (Bédard et al. 2017; Raymond, Sirois, et al. 2017; Nasr et al. 2018). The workflow to define statistical and spatial distributions of the bedrock thermal conductivity from three distinct dataset sources at a regional scale described in this work is believed to be an original contribution (Figure 5). The same workflow could be used in other sedimentary basins, where similar sources of data, enclosing TRT, laboratory measurements and geophysical well logs are likely available or could be modified if less data sources are available to map the thermal conductivity of other geological regions with a similar geostatistical approach. Mapping the thermal conductivity of the subsurface can become an asset to share knowledge gained from previous GCHP installations and facilitate system design while this pioneer work sets guidelines to follow with an original methodology that can be reproduced in other geological environments with significant GCHP market development potential.

The comparison of each data source allowed identifying field scale effects for thermal conductivity assessment of host rock from the laboratory to the field, as described by Luo 
et al. (2016). Here, it was chosen to adjust the average thermal conductivity obtained from laboratory analysis on rock samples that are conducted on a centimeter scale to match the average thermal conductivity inferred in the field with TRTs conducted on a meter scale. Further work could be done to evaluate the millimetric distribution of thermal conductivity within samples using infrared scanning (Popov et al. 1999; Jorand et al. 2013) to subsequently model conductive heat transfer within at least decimetric samples (Jorand et al. 2015) and properly evaluate how to upscale thermal conductivity assessments. This has been attempted for the study of deep geothermal reservoirs, but never achieved for GCHP systems, where the radius of influence reached by a TRT and the operation of a system should be both considered. Additional laboratory analysis and numerical modeling is needed to go beyond the pragmatic approach used in the study to adjust the average thermal conductivity for each data source, but also to better understand the impact of groundwater flow on the assessment of the bulk subsurface thermal conductivity (Sarah Signorelli et al. 2007; Raymond et al. 2011b; Dehkordi and Schincariol 2014; Ferguson 2015). The Beauharnois thermostratigraphic unit, which showed an opposite behavior than other units with a thermal conductivity that was higher when evaluated in the field with TRTs compared to laboratory analysis on rock samples and geophysical well log interpretations, is dominantly made of dolomite. This rock lithology is known to be the host of gas reservoirs in the SLL (Bertrand et al. 2003; Lavoie 2009; Lavoie et al. 2009), where porosity up to $15 \%$ and permeability that reached $70 \mathrm{mD}$ has been created by fracture-controlled calcite dissolution in the dolomitic facies, referred as hydrothermal dolomites (Bertrand et al. 2003). If similar permeability exists in near-surface dolomites of the Beauharnois Formation, this could 
facilitate groundwater flow and explain the increasing thermal conductivity that is observed when comparing laboratory to in situ heat transfer experiments, as evidenced by Vieira et al. (2017). While the inventory of thermal conductivity achieved in this work is in support of this hypothesis, further work is needed to properly characterize the in situ flow properties of this unit.

A simulated thermal conductivity map using SGS is a significant achievement for the SLL. This option to spatialize data was selected due to the large amount of well log data, which can be used to properly evaluate the thermal conductivity variance for each thermostratigraphic unit (Table 3; Figure 7), and the fair amount of near-surface thermal conductivity evaluations from rock samples and TRT analysis to interpolate data in 2D space. This contrasts with previous mapping of thermal conductivity, where a map with points was plotted on top of a geological map (Raymond, Sirois, et al. 2017) or a range of data was assigned to geological units based on a limited number of laboratory analysis on rock samples for each unit (Di Sipio et al. 2014). The preceding two approaches are limited and hardly illustrate the spatial variation of thermal conductivity. Attempts were previously made to interpolate thermal conductivity with geostatistical simulations, but to a smaller area and with fewer data (Raymond, Malo, et al. 2017; Malmberg et al. 2018). Alternative approaches can be to interpolate geological information from stratigraphic descriptions in 2D and then compute the effective thermal conductivity, similar to work made by Teza et al. (2015), or analyze geophysical data to constrain a 3D model of thermal conductivity, as done with the analysis of airborne aeromagnetic surveys (Santilano et al. 2015). Evaluating thermal conductivity distribution in 3D space is critical because borehole depth can vary among GCHP systems, but requires a large 
amount of data and processing time. The approach followed in this work for the SLL was to remove the thermal contribution associated to the unconsolidated sediments cover and to map the thermal conductivity of the bedrock in $2 \mathrm{D}$ space with laboratory and TRT analyses, which are characteristic of near-surface conditions. However, it is required to recalculate the bulk thermal conductivity, taking the unconsolidated sediments thickness into account, when extracting information from the map in the scope of designing geothermal systems, as evidenced by the sizing calculation performed for a mid-size apartment building requiring 30 vertical GHE (Table 6). The sizing calculation based on the bulk thermal conductivity extracted from the maps suggest that the geostatistical simulations are reliable, but the maps do not have the accuracy of a TRT, which is on the order of 5 to $10 \%$ when the TRT duration is above $50 \mathrm{~h}$ (Witte 2013). However, the accuracy of a TRT can be above $10 \%$ when the test duration is shorter (Austin et al. 2000). The map validation made by comparing the bulk thermal conductivity from twelve additional TRT data revealed that the map accuracy is on average twice that of a TRT (Table 6), although this is difficult to generalize and depends on data availability for given locations, and on the other hand, the TRT duration. The standard deviation of the simulated thermal conductivity (Figure 8c), which is thought to be representative of the map uncertainty, can be below $0.4 \mathrm{~W} \mathrm{~m}^{-1} \mathrm{~K}^{-1}$ where data density is sufficient and is thus close to TRT accuracy. The next step of this research is to properly assess the thermal conductivity and vertical distribution of the unconsolidated sediments, with laboratory measurements made on samples, such that an interpolated 2D map of thermal conductivity could be made for the unconsolidated sediments. The $2 \mathrm{D}$ thermal conductivity maps of the unconsolidated sediments and the bedrock could finally be 
combined with information of the bedrock depth to provide a valuable 3D model for the thermal conductivity of the SLL.

The efforts made to compile data from different sources and compute the statistical and spatial distributions of thermal conductivity allowed increasing the ground knowledge to eventually help better design and simulate GCHP systems. Until recently, designers were limited to thermal conductivity databases built only from laboratory analysis made on small-scale samples classified according to rock type. Such databases, commonly provided with GHE design programs like Earth Energy Designer (Bolcon AB 2016), do not enclose thermal conductivity assessments from in situ TRTs and the spatial distribution cannot be taken into account in the design process limited to such databases. The map prepared for the SLL brings GHE design to a high level, where input thermal conductivity data can be selected from field observations in this specific geological province. However, the information provided with the maps is not to replace an in situ assessment of thermal conductivity like a TRT. The information is given for a regional scale, while heterogeneity of rock units that can influence TRT can occur at the site scale, where GCHP systems are installed. Surprisingly, North American standards, suggesting to conduct one to three TRTs when the capacity of the GCHP system vary from less than 45 to more than $100 \mathrm{~kW}$ (ANSI/CSA, 2016), do not rely on the potential subsurface thermal conductivity although it is the most important factor affecting GHE length. The authors believe that the map provided in this manuscript could be used to complement such guideline. In fact, the maps can be used to design a GCHP system when uncertainty about the bedrock thermal conductivity and the associated GHE length does not justify a TRT to be conducted for GCHPs of small capacity, like residential and small commercial 
buildings, or to do a preliminary design of a GCHP system to determine if a TRT is really needed. The sizing calculations performed in this work illustrate how the maps can be used for a preliminary design. The medium-size apartment with $83 \mathrm{~kW}$ peak loads, supplied by the GCHP system subject to sizing calculations, revealed that the maps were reliable enough for half of the comparative cases, where borehole length variability was less than $10 \%$ when comparing sizing results obtain with subsurface thermal conductivity from the maps and TRTs. One the other hand, a TRT would have been useful for the other half of the comparative cases to save on borehole length. In the case of a mid- to large-size building, it is recommended to validate the preliminary design supported by the maps with an in situ assessment as it is commonly done for GCHPs of large capacity. The maps can still be useful for prefeasibility studies of large-size systems to help narrow installation cost and demonstrate the needs of a TRT.

\section{Acknowledgements}

This research was funded by the Natural Sciences and Engineering Research Council of Canada under the Engage and Discovery programs with partnership between the Institut national de la recherche scientifique and SNC-Lavalin. The following companies and organization have significantly contributed to this research by sharing TRT data and are acknowledged: Akonovia, GBI, Richelieu Hydrogéologie and Canadian GeoExchange Coalition.

\section{References}


ANSI/CSA. 2016. Design and installation of ground source heat pump systems for commercial and residential buildings. Standard No. C448 Series-16, American National Standard Institute/CSA Group, Toronto.

Austin, W., Yavuzturk, C., and J.D. Spitler. 2000 Development of an In-Situ System and Analysis Procedure for Measuring Ground Thermal Properties. ASHRAE Trans, 106, (1): 365-379.

Badache, M., P. Eslami-Nejad, M. Ouzzane, Z. Aidoun, and L. Lamarche. 2016. A new modeling approach for improved ground temperature profile determination. Renewable Energy, 85:436-444.

Beck, A. 1957. A steady state method for the rapid measurement of the thermal conductivity of rocks. Journal of Scientific Instruments, 34(5):186-189.

Beck, A. E., and J. M. Beck. 1958. On the measurement of the thermal conductivities of rocks by observations on a divided bar apparatus. Eos, Transactions American Geophysical Union, 39(6):1111-1123.

Bédard, K., F.-A. Comeau, E. Millet, J. Raymond, M. Malo, and E. Gloaguen. 2016. Évaluation des ressources géothermiques du bassin des Basses-Terres du SaintLaurent. Report 1659, Institut national de la recherche scientifique - Centre Eau Terre Environnement, Quebec City. http://espace.inrs.ca/4845/1/R001659.pdf

Bédard, K., F.-A. Comeau, J. Raymond, M. Malo, and M. Nasr. 2017. Geothermal Characterization of the St. Lawrence Lowlands Sedimentary Basin, Québec, Canada. Natural Resources Research, 27(4):479-502.

Bernier, M. 2000. A Review of the cylindrical heat source method for the design and analysis of vertical ground-coupled heat pump systems. In Proceedings of the 
Fourth International Conference on Heat Pumps in Cold Climates Conference, Caneta Research Inc, Aylmer.

Bertrand, R., A. Chagnon, M. Malo, Y. Duchaine, D. Lavoie, and M. Savard. 2003. Sedimentologic, diagenetic and tectonic evolution of the Saint-Flavien gas reservoir at the structural front of the Quebec Appalachians. Bulletin of the Canadian Petroleum Geology, 51(2):126-154.

Bolcon AB. 2016. Earth Energy Designer version 4. Update Manual, Bolcon, Lund.

Bozdağ, S.., B. Turgut, H. Paksoy, D. Dikici, M. Mazman, and H. Evliya. 2008. Ground water level influence on thermal response test in Adana, Turkey. International Journal of Energy Research, 32(7):629-633.

Brisebois, D., and J. Brun. 1994. La plate-forme du Saint-Laurent et les Appalaches. In Géologie du Québec, Ministère des ressources naturelles, Quebec City.

Bristow, K. L., G. J. Kluitenberg, and R. Horton. 1994. Measurement of soil thermal properties with a dual-probe heat-pulse technique. Soil Science Society of America Journal, 58(5):1288-1294.

Bristow, K. L., and R. D. White. 1994. Comparison of single and dual probes for measuring soil thermal properties with transient heating. Australian Journal of Soil Research, 32(3):447-464.

British Geological Survey. 2011. Temperature and thermal properties (detailed). Report GR_999999/14, British Geological Survey, Nottingham.

Canadian GeoExchange Coalition. 2012. The state of the Canadian geothermal heat pump industry 2011 - Industry survey and market analysis. Canadian GeoExchange Coalition, Montreal. 
Carrier, M.-A., R. Lefebvre, C. Rivard, M. Parent, J.-M. Ballard, N. Benoit, H. Vigneault, C. Beaudry, X. Malet, M. Laurencelle, J.-S. Gosselin, P. Ladevèze, R. Thériault, I. Beaudin, A. Michaud, A. Pugin, R. Morin, H. Crow, E. Gloaguen, E. Bleser, A. Martin, and D. Lavoie. 2013. Portrait des ressources en eau souterraine en Montérégie Est, Québec, Canada. PACES final report R-1433, Institut national de la recherche scientifique - Centre Eau Terre Environnement, Quebec City. http://espace.inrs.ca/1639/1/R001433.pdf

Castonguay, S., D. Lavoie, J. Dietrich, and J.-Y. Laliberté. 2010. Structure and petroleum plays of the St. Lawrence Platform and Appalachians in southern Quebec: insights from interpretation of MRNQ seismic reflection data. Bulletin of Canadian Petroleum Geology, 58(3):219-234.

Claesson, J., and G. Hellström. 2011. Multipole method to calculate borehole thermal resistances in a borehole heat exchanger. HVAC\&R Research, 17(6):859-911.

Clauser, C. 2014a. Thermal Storage and Transport Properties of Rocks, I: Heat Capacity and Latent Heat. In H. Gupta (Ed.), Encyclopedia of Solid Earth Geophysics (pp. 1423-1431). Springer Netherlands.

Clauser, C. 2014b. Thermal Storage and Transport Properties of Rocks, II: Thermal Conductivity and Diffusivity. In H. Gupta (Ed.), Encyclopedia of Solid Earth Geophysics (pp. 1431-1448). Springer Netherlands.

Comeau, F.-A., D. Kirkwood, M. Malo, E. Asselin, and R. Bertrand. 2004. Taconian mélanges in the parautochthonous zone of the Quebec Appalachians revisited: implications for foreland basin and thrust belt evolution. Canadian Journal of Earth Sciences, 41(12):1473-1490. 
Comeau, F.-A., K. Bédard, and M. Malo. 2013. Lithostratigraphie standardisée du bassin des Basses-Terres du Saint-Laurent basée sur l'étude des diagraphies. Report R1442, Institut national de la recherche scientifique - Centre Eau Terre Environnement, Quebec City. http://espace.inrs.ca/1645/1/R001442.pdf

Comeau, F.-A., J. Raymond, M. Malo, C. Dezayes, and M. Carreau. 2017. Geothermal potential of Northern Québec: A regional assessment. GRC Transactions, 41.

Dehkordi, S. E., and R. A. Schincariol. 2014. Effect of thermal-hydrogeological and borehole heat exchanger properties on performance and impact of vertical closedloop geothermal heat pump systems. Hydrogeology Journal, 22(1):189-203.

Di Sipio, E., A. Galgaro, E. Destro, G. Teza, S. Chiesa, A. Giaretta, and A. Manzella. 2014. Subsurface thermal conductivity assessment in Calabria (southern Italy): a regional case study. Environmental Earth Sciences, 72:1383-1401.

Engineering ToolBox. 2003. Thermal conductivity of common materials and gases. Retreived from the Internet: https://www.engineeringtoolbox.com/thermalconductivity-d_429.html

Eppelbaum, L., I. Kutasov, and A. Pilchin. 2014. Applied Geothermics. Sprigner, New York.

Farouki, O. T. 1981. Thermal properties of soil. United States Army Corps of Engineers, Cold Regions Research and Engineering Laboratory, Hanover.

Feininger, T., and A. K. Goodacre. 1995. The eight classical Monteregian hills at depth and the mechanism of their intrusion. Canadian Journal of Earth Sciences, 32(9):1350-1364. 
Ferguson, G. 2015. Screening for heat transport by groundwater in closed geothermal systems. Groundwater, 53(3):503-506.

Fuchs, S., and A. Förster. 2013. Well-log based prediction of thermal conductivity of sedimentary successions: A case study from the north german basin. Geophysical Journal International, 196(1):291-311.

Fujii, H., H. Okubo, K. Nishi, R. Itoi, K. Ohyama, and K. Shibata. 2009. An improved thermal response test for U-tube ground heat exchanger based on optical fiber thermometers. Geothermics, 38(4):399-406.

Gasior, I., and A. Przelaskowska. 2014. Estimating thermal conductivity from core and well log data. Acta Geophysica, 62(4):785-801.

Gegenhuber, N., and J. Schoen. 2012. New approaches for the relationship between compressional wave velocity and thermal conductivity. Journal of Applied Geophysics, 76:50-55.

Gehlin, S., and B. Nordell. 2003. Determining undisturbed ground temperature for thermal response test. ASHRAE Transactions, 109:151-156.

Globensky, Y. 1987. Géologie des Basses-Terres du Saint-Laurent. Report MM 85-02, Ministère de l’Énergie et des Ressources du Québec, Quebec City.

Globensky, Y. 1993. Lexique stratigraphique canadien. Volume V-B : région des Appalaches, des Basses-Terres du Saint-Laurent et des Îles de la Madeleine. Report No. DV-91-23, Gouvernement du Québec, Ministère de l'énergie et des ressources, Direction générale de l'exploration géologique et minérale, Quebec City. 
Goovaerts, P. 1997. Geostatistics for Natural Resources Evaluation. Oxford University Press, New York.

Gosnold, W. D., M. R. McDonald, R. Klenner, and D. Merriam. 2012. Thermostratigraphy of the Williston Basin. GRC Transactions, 36:663-670.

Gosselin, J.-S. 2018. PyGLD, Python library to do ground loop design calculations. Available on the Internet: https://github.com/jnsebgosselin/pygld. Last retrieved on February 2019.

Harris, A., S. Kazachenko, R. Bateman, J. Nickerson, and M. Emanuel. 2014. Measuring the thermal conductivity of heat transfer fluids via the modified transient plane source (MTPS). Journal of Thermal Analysis and Calorimetry, 116(3):13091314.

Jaziri, N., J. Raymond, and M. Boisclair. 2016. Performance evaluation of a ground coupled heat pump system with a heat injection test analysis. In Proceedings of the 69th Canadian Geotechnical Conference, Vancouver.

Jessop, A. M., V. S. Allen, W. Bentkowski, M. Burgess, M. Drury, A. S. Judge, T. Lewis, J. Majorowicz, J. C. Mareschal, and A. E. Taylor. 2005. The Canadian geothermal data compilation. Open File 4887, Ottawa.

Jorand, R., C. Clauser, G. Marquart, and R. Pechnig. 2015. Statistically reliable petrophysical properties of potential reservoir rocks for geothermal energy use and their relation to lithostratigraphy and rock composition: The NE Rhenish Massif and the Lower Rhine Embayment (Germany). Geothermics, 53:413-428. 
Jorand, R., C. Vogt, G. Marquart, and C. Clauser. 2013. Effective thermal conductivity of heterogeneous rocks from laboratory experiments and numerical modeling. Journal of Geophysical Research: Solid Earth, 118(10):5225-5235.

Journel, A. G., and C. J. Huijbregts. 1968. Mining geostatistics. The Blackburn Press, New York.

Kavanaugh, S. P., and K. Rafferty. 2014. Ground-source heat pumps: design of geothermal systems for commercial and institutional buildings. American Society of Heating, Refrigerating and Air-Conditioning Engineers, Atlanta.

Lamarche, L., and B. Beauchamp. 2007. A new contribution to the finite line-source model for geothermal boreholes. Energy and Buildings, 39(2):188-198.

Larocque, M., V. Cloutier, J. Levison, and E. Rosa. 2018. Results from the Quebec Groundwater Knowledge Acquisition Program. Canadian Water Resources Journal / Revue Canadienne Des Ressources Hydriques, 43(2):69-74.

Laroque, M., S. Gagné, D. Barnetche, G. Meyzonnat, M. H. Graveline, and M. A. Ouellet. 2015. Projet dê connaissance des eaux souterraines du bassin versant de la zone Nicolet êt de la partie basse de la zone Saint-François. PACES final report, Université du Québec à Montréal, Montreal.

Lavoie, D. 2008. Chapter 3 Appalachian Foreland Basin of Canada. In A. D. Miall (Ed.), Sedimentary Basins of the World (Vol. 5, pp. 65-103). Elsevier.

Lavoie, D. 2009. Porosity and permeability measurements for selected Paleozoic samples in Quebec. Open File 6084, Geological Survey of Canada, Ottawa.

Lavoie, D., N. Pinet, J. Dietrich, S. Castonguay, A. P. Hamblin, and P. Giles. 2009. Petroleum resource assessment, Paleozoic successions of the St. Lawrence 
Platform and Appalachians of eastern Canada. Open File 6174, Geological Survey of Canada, Ottawa.

Légaré-Couture, G., Y. Leblanc, M. Parent, K. Lacasse, and S. Campeau. 2018. Threedimensional hydrostratigraphical modelling of the regional aquifer system of the St. Maurice Delta Complex (St. Lawrence Lowlands, Canada). Canadian Water Resources Journal, 43(2):92-112.

Lehr, C., and I. Sass. 2014. Thermo-optical parameter acquisition and characterization of geologic properties: a 400-m deep BHE in a karstic alpine marble aquifer. Environmental Earth Sciences, 72:1403-1419.

Luo, J., J. Jia, H. Zhao, Y. Zhu, Q. Guo, C. Cheng, L. Tan, W. Xiang, J. Rohn, and P. Blum. 2016. Determination of the thermal conductivity of sandstones from laboratory to field scale. Environmental Earth Sciences, 75(16):1158.

Majorowicz, J. A., S. E. Grasby, and W. C. Skinner. 2009. Estimation of shallow geothermal energy resource in Canada: heat gain and heat sink. Natural Resources Research, 18(2):95-108.

Malmberg, M., J. Raymond, L. Perozzi, E. Gloaguen, C. Mellqvist, G. Schwarz, and J. Acuña. 2018, Development of a thermal conductivity map of Stockholm. In Proceedings of IGHSPA Research Conference, Stockholm.

Midttømme, K., E. Roaldset, and P. Aagaard. 1998. Thermal conductivity of selected claystones and mudstones from England. Clay Minerals, 33(1):131-145.

Nasr, M., J. Raymond, and M. Malo. 2015. Évaluation en laboratoire des caractéristiques thermiques du bassin sédimentaire des Basses-Terres du Saint-Laurent. In 
Proceedings of the 68th Canadian Geotechnical Conference and 7th Canadian Permafrost Conference, Québec City.

Nasr, M., J. Raymond, M. Malo, and E. Gloaguen. 2018. Geothermal potential of the St. Lawrence Lowlands sedimentary basin from well log analysis. Geothermics, 75:68-80.

Ouzzane, M., P. Eslami-Nejad, M. Badache, and Z. Aidoun. 2015. New correlations for the prediction of the undisturbed ground temperature. Geothermics, 53:379-384.

Perozzi, L., J. Raymond, S. Asselin, E. Gloaguen, M. Malo, and C. Bégin. 2016.

Simulation géostatistique de la conductivité thermique : application à une région de la communauté métropolitaine de Montréal. Report R1663, Institut national de la recherche scientifique - Centre Eau Terre Environnement, Quebec City. http://espace.inrs.ca/3374/1/R001663.pdf

Philippe, M., M. Bernier, and D. Marchio. 2010. Sizing calculation spreadsheet - Vertical geothermal borefields. ASHRAE Journal, 52(7):20-28.

Popov, Y. A., D. F. C. Pribnow, J. H. Sass, C. F. Williams, and H. Burkhardt. 1999. Characterization of rock thermal conductivity by high-resolution optical scanning. Geothermics, 28(2):253-276.

Raymond, J., L. Lamarche, and M.-A. Blais. 2014. Quality control assessment of vertical ground heat exchangers. ASHRAE Transactions, 120(2):SE-14-014.

Raymond, J., R. Therrien, L. Gosselin, and R. Lefebvre. 2011a. A review of thermal response test analysis using pumping test concepts. Ground Water, 49(6):932945. 
Raymond, J., R. Therrien, L. Gosselin, and R. Lefebvre. 2011b. Numerical analysis of thermal response tests with a groundwater flow and heat transfer model. Renewable Energy, 36(1):315-324.

Raymond, J. 2018. Colloquium 2016: Assessment of subsurface thermal conductivity for geothermal applications. Canadian Geotechnical Journal, 55(9):1209-1229.

Raymond, J., M. Malo, L. Lamarche, L. Perozzi, E. Gloaguen, and C. Bégin. 2017. New methods to spatially extend thermal response test assessments. In Proceedings of IGHSPA Technical/Research Conference and Expo, Denver.

Raymond, J., C. Sirois, M. Nasr, and M. Malo. 2017. Evaluating the geothermal heat pump potential from a thermostratigraphic assessment of rock samples in the St. Lawrence Lowlands, Canada. Environmental Earth Sciences, 76(2):83.

Ross, M., M. Parent, B. Benjumea, and J. Hunter. 2006. The late Quaternary stratigraphic record northwest of Montréal: regional ice-sheet dynamics, ice-stream activity, and early deglacial events. Canadian Journal of Earth Sciences, 43(4):461-485.

Salomone, L. A., J. I. Marlowe, and P. A. Joyner. 1989. Soil and rock classification according to thermal conductivity : design of ground-coupled heat pump systems. Electric Power Research Institute, Palo Alto.

Santilano, A., A. Manzella, A. Donato, D. Montanari, G. Gola, E. Di Sipio, E. Destro, A. Giaretta, A. Galgaro, G. Teza, A. Viezzoli, and A. Menghini. 2015. Shallow Geothermal Exploration by Means of SkyTEM Electrical Resistivity Data: An Application in Sicily (Italy). In G. Lollino, A. Manconi, J. Clague, W. Shan, \& M. Chiarle (Eds.), Engineering Geology for Society and Territory - Volume 1: 
Climate Change and Engineering Geology (pp. 363-367). Springer International Publishing, Cham.

Sass, I., and A. E. Götz. 2012. Geothermal reservoir characterization: a thermofacies concept. Terra Nova, 24(2):142-147.

Shabbir, G., A. Maqsood, and C. A. Majid. 2000. Thermophysical properties of consolidated porous rocks. Journal of Physics D: Applied Physics, 33(6):658661.

Sharma, P. V. 2002. Environmental and engineering geophysics. Cambridge University Press, Cambridge.

Signorelli, S., and T. Kohl. 2004. Regional ground surface temperature mapping from meteorological data. Global and Planetary Change, 40(3-4):267-284.

Signorelli, S., S. Bassetti, D. Pahud, and T. Kohl. 2007. Numerical evaluation of thermal response tests. Geothermics, 36(2):141-166.

Srivastava, R. M. 1994. An overview of stochastic methods for reservoir characterization. In J. M. Yarus; R. L. Chambers (eds), Stochastic modeling and geostatistics: principles, methods, and case studies. American Association of Petroleum Geologists, Vol. 3, Tulsa.

Teza, G., A. Galgaro, E. Destro, and E. Di Sipio. 2015. Stratigraphy modeling and thermal conductivity computation in areas characterized by Quaternary sediments. Geothermics, 57:145-156.

Tran Ngoc, T. D., R. Lefebvre, E. Konstantinovskaya, and M. Malo. 2014. Characterization of deep saline aquifers in the Bécancour area, St. Lawrence 
Lowlands, Québec, Canada: Implications for $\mathrm{CO} 2$ geological storage. Environmental Earth Sciences, 72(1):119-146.

Vasseur, G., F. Brigaud, and L. Demongodin. 1995. Thermal conductivity estimation in sedimentary basins. Tectonophysics, 244(1-3):167-174.

Vieira, A., M. Alberdi-Pagola, P. Christodoulides, S. Javed, F. Loveridge, F. Nguyen, F. Cecinato, J. Maranha, G. Florides, I. Prodan, G. V. Lysebetten, E. Ramalho, D. Salciarini, A. Georgiev, S. Rosin-Paumier, R. Popov, S. Lenart, S. E. Poulsen, and G. Radioti. 2017. Characterisation of Ground Thermal and Thermo-Mechanical Behaviour for Shallow Geothermal Energy Applications. Energies, 10(12).

Waples, D. W., and J. S. Waples. 2004a. A review and evaluation of specific heat capacities of rocks, minerals, and subsurface fluids. Part 1: minerals and nonporous rocks. Natural Resources Research, 13(2):97-122.

Waples, D. W., and J. S. Waples. 2004b. A review and evaluation of specific heat capacities of rocks, minerals, and subsurface fluids. Part 2: fluids and porous rocks. Natural Resourcês Research, 13(2):123-130.

Witte, H. J. L. 2013. Error analysis of thermal response tests. Applied Energy, 109(0):302-311. 